\title{
Who Cares for Reputation? Individual Differences and Concern for Reputation
}

Article in Current Psychology · July 2014

DOI: $10.1007 /$ s12144-014-9249-y

CITATIONS

2

3 authors:

\section{Nicoletta Cavazza}

Università degli Studi di Modena e Reggio Em. .

37 PUBLICATIONS 226 CITATIONS

SEE PROFILE

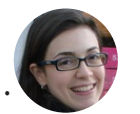

\section{Margherita Guidetti}

Università degli Studi di Modena e Reggio E... 18 PUBLICATIONS 88 CITATIONS

SEE PROFILE

\section{Stefano Pagliaro}

Università degli Studi G. d'Annunzio Chieti e...

40 PUBLICATIONS 371 CITATIONS

SEE PROFILE

Some of the authors of this publication are also working on these related projects: 
RUNNING HEAD: Personality and Concern for Reputation

\title{
Who Cares for Reputation? Individual Differences and Concern for Reputation
}

\author{
$\underline{\text { Nicoletta Cavazza }}^{1}, \underline{\text { Margherita Guidetti }}^{1}$, and Stefano Pagliaro ${ }^{2}$ \\ ${ }^{1}$ Università di Modena e Reggio Emilia \\ ${ }^{2}$ Seconda Università di Napoli
}

\begin{abstract}
Reputation is highly important within groups as it provides a number of benefits, both instrumental (including access to valuable resources and the likelihood to influence others) and symbolic ones (e.g., satisfaction of fundamental esteem needs). In the present paper, we proposed and found that the degree to which people are concerned about their reputation is sensitive to personality differences. We found evidence that prevention focus and others' approval as contingency of self-worth predict concern for reputation via self-monitoring orientation (mediation model). Results are discussed in terms of reputation management, and future research avenues are proposed.
\end{abstract}

KEYWORDS: Concern for Reputation; Prevention Focus; Self-worth; Self-Monitoring 
In psychosocial terms, individual reputation is intended as a social representation (made of a complex set of information, beliefs, judgments, and social expectations) constructed by the members of a community (Bromley, 1990; Emler, 1990). People have more than one reason to be motivated to reach and maintain a good reputation. Even though nowadays a bad reputation rarely endangers life as it did in medieval societies when the widespread belief that an individual was a heretic or a witch took him or her to the stake, a good reputation remains a personal assets. First, it assures access to valuable resources (e.g., customers, collaborative partners, social exchanges based on trust), because we often rely on reputation information when selecting our interaction partner, even in the case of business associates, friends, or romantic partners (Tinsley, O’Connor, \& Sullivan, 2002). Moreover, possessing a favourable reputation increases the likelihood of being effective in influencing other people (Hochwarter, Ferris, Zinko, Arnell, \& James, 2007). Beyond these instrumental functions, it is worth considering that individuals also express an intrinsic motivation to be viewed positively by the groups to which they belong: In his widely adopted classification, Maslow (1943) cited the desire for reputation among the esteem needs. Thanks to these individual advantages, reputation is also a powerful tool of social control: The fear of social blame and exclusion promotes cooperation and pro-social behaviours (Emler, 1990; Gordon, 1989; Griskevicius, Tybur, \& Van den Bergh, 2010; Semmann, Krambeck, \& Milinski, 2005).

However, whereas gaining a good reputation is a difficult task, earning a bad name is easy, because negative behaviours are generally perceived as more diagnostic than positive ones, particularly when they relate to a moral dimension (Skowronski, \& Carlston, 1987; see also, Ellemers, Pagliaro, \& Barreto, in press). Indeed, a single observed honest behaviour is just a little step toward good reputation building, whereas a single public dishonest behaviour is enough to tarnish one's reputation. In addition, personal reputation is context-specific: The same individual can enjoy a very good name in one of his/her life domain (e.g., group of 
friends) and, at the same time, a bad reputation in another (e.g., work organization). This is why nobody is permanently safe after having reached a positive reputation in one of the groups to which s/he belongs: The maintenance of one's good reputation and exporting it to other life domains is a task engaging individuals throughout life.

Despite psychosocial and anthropological research that has convincingly highlighted the importance of reputation as a personal and social regulation tool, little attention has been devoted to understanding whether individuals' concern for reputation varies as a function of contingent context features (e.g., characterizing the reference groups), and how it relates to personality traits. Indeed, recent insights suggest that individual concern for reputation may be less stable than one might imagine (Anderson \& Shirako, 2008; Cavazza, Pagliaro, \& Guidetti, in press). However, some personality traits may also focus individuals' attention to their reputation, thus making them more (or less) concerned about it. Research on social image (e.g., Rodriguez Mosquera, Uskul, \& Cross, 2011; Ybarra, Park, Stanik, \& Lee, 2012) showed that everyone is attentive to personal reputation, but it is plausible that some individuals are more attentive than others.

Which personality traits may be associated with individuals' concern for their reputation? Since maintaining a good reputation has to do with the likelihood to receive positive social feedback and avoid social blame, it seems reasonable to advance that people drawing their self-esteem from others' approval and those generally oriented to prevent possible social and personal damages should be particularly worried about their reputation. Furthermore, these traits should stimulate individual motivation to carefully monitor one's social environment (i.e., implicit social norms and expectations) and regulate behaviour in order to reach positive social feedback and prevent negative outcomes from happening. Since personal reputation is malleable and context specific, the concern of achieving a shared positive name should also be affected by whether -- and to what extent -- individuals are 
inclined to detect time by time context specific social demands, i.e. their self-monitoring orientation.

It is for these reasons that in the present paper we investigate whether people's concern for reputation is influenced by relatively stable individual traits orienting them to be particularly interested in preventing self-damages (i.e., prevention focus, Higgins, 1998), gaining others' approval (i.e., others' approval as a contingency of self-worth, Crocker \& Wolfe, 2001; Crocker, Luhtanen, Cooper, \& Bouvrette, 2003) and, in turn, keep a high monitoring of implicit social norms and expectations (i.e. self-monitoring, Snyder, 1974).

\section{Prevention Focus}

Regulatory Focus Theory (Higgins, 1998) proposed two distinct types of selfregulatory systems, as both relatively stable traits and situationally induced states. Promotionfocused individuals, driven by growth and development needs, are trying to achieve their ideal selves, reflecting wishes, hopes and aspiration, and thus are mainly concerned with maximizing positive outcomes and pursuing success and accomplishment. Reversely, prevention-focused individuals, driven by security needs, are seeking to match their ought selves, reflecting duties, obligations and responsibilities, and thus are mainly concerned with minimizing negative outcomes and preventing failures or losses. Strategically, promotionfocused individuals are characterised by readiness and motivation to ensure gains, whereas prevention-focused individuals are characterised by vigilance and motivation to ensure nonlosses (Brockner \& Higgings, 2001).

As outlined above, one's good name is more easily lost than gained, thus the tarnish of personal reputation represents a threatening negative outcome. As such, the threat of a negative outcome should be particularly alarming for prevention focus individuals. However, empirical evidence supporting this inference is scant. In research conducted by Lalwani, Shrum, and Chiu (2009), prevention focus was found to predict impression management, which refers to an attempt to consciously distort one's self-reported actions in a socially 
approved way in order to create and maintain a favourable image in an audience (Paulhus, 1984). Since impression management is associated with the maintenance of one's face (Cupach \& Metts, 1994), it is conceptually linked to reputation (Bromley, 1993).

To the best of our knowledge, to date, no research has shown that the vigilance characterizing prevention-focused persons enhances their self-monitoring orientation. However, we would plausibly expect that vigilance associated with prevention focus stimulates the self-monitoring proneness, in order to detect the social standards in respect to which regulate behaviour, and in turn, it intensifies individual's concern for maintaining personal reputation.

\section{Others' Approval as Contingency of Self-Worth}

To enjoy a good reputation means to feel approved, at least within the boundary of one's reference group(s). Approval from generalized others is important for everyone's selfesteem (Cooley, 1902; Mead, 1934; Leary \& Baumeister, 2000); however, the degree of its centrality varies across individuals. Most research on self-esteem has focused on the level of this trait, trying to investigate its psychological and behavioural outcomes. In contrast, Crocker and colleagues (Crocker \& Wolfe, 2001; Crocker, Luhtanen, Cooper, \& Bouvrette, 2003) argued that it is not the quantity but rather the quality and the contingency of selfesteem as related to affective reactions and social behaviour that is important. They proposed a model of global self-esteem emphasizing the contingencies of self-worth, defined as domains in which individuals invested in their self-esteem. Consequently, self-esteem fluctuates as a function of perceived successes or failures in these relevant domains. These contingencies have cognitive, affective, and motivational implications, and lead to behaviour aimed at succeeding in the domains on which one's self-esteem is based.

Crocker and colleagues (2003) developed the Contingencies of Self-Worth Scale assessing seven different sources of self-esteem arrayed on a continuum from external/interpersonal to internal/intrapersonal contingencies. One of these dimensions, 
namely others' approval, is of particular interest for our purpose because the more important others' approval is for an individual's self-esteem, the more s/he should be motivated to detect and comply with contextual implicit social norms and concerned with the maintenance of her/his reputation. Moreover, as others' approval is an external contingency of self-worth, based on superficial or unstable aspects such as achievement or continual validation from others, it should enhance the individual self-monitoring orientation (Briggs \& Cheeck, 1988; Briggs, Cheeck \& Buss, 1980).

\section{Self-monitoring}

Reputation building is a process at least in part under individual control. In order to build a good reputation, individuals have to manage behaviours in such a way as to hide improper actions and to put forward behaviours meeting others' expectations and social norms (Goffman, 1959). Self-monitoring orientation reflects individual differences in sensitivity to social norms and motivation to act in an appropriate way in every social context (Snyder, 1974). High (vs. low) self-monitors are more able to detect implicit social expectations and more concerned with the demands of social situations (Patterson, 1983; Snyder \& Gangestad, 1986). Studies (e.g., Cavazza, Graziani, \& Guidetti, 2011; Perrine \& Aloise-Young, 2004) suggest a link between self-monitoring and compliance to implicit social pressure; these implicit norms need to be recognised and are strategically used for selfpresentation purposes (Goffman, 1959), which are a core aspect of self-monitoring.

Indeed, a reappraisal of the construct (and of the assessment scale associated with it), indicate that self-monitoring taps into individual differences in the tendency to engage in impression management strategies characterised by the active construction of social appearances and public selves "designed to achieve social ends, a process perhaps most appropriately referred to as image projection" (Gangestad \& Snyder, 2000, p. 546). In sum, high self-monitors are firstly characterized by status enhancement motive (Gangestad \& Snyder, 2000) and may enact this motive by engaging in impression management behaviours. 
Hence, this motive should also focus their attention on their reputation (as a long term, shared and less micro-context specific product of impressions) making them particularly concerned.

On the basis of this evidence, we expect a link between self-monitoring and concern for reputation, since individuals more motivated and able to cultivate a positive social image should be more concerned about their name.

\section{The Present Research}

In the present research we aimed to test whether concern for personal reputation varies as a function of personality characteristics. In particular, according to the above-mentioned rationale, we expect that both others' approval as contingency of self-worth and prevention focus stimulate high motivation to comply with implicit social norms (i.e., self-monitoring; Hypothesis1). We further anticipate that this motivation to appear adequate in the social context induces high concern for personal reputation (Hypothesis 2). To sum up, we hypothesize a mediation model in which the effect of prevention focus and others' approval as contingency of self-worth predict concern for reputation via self-monitoring orientation.

\section{Method}

Participants. A total of 238 Italian students were recruited (convenience sample) during a university lecture or through a mailing list, and were asked to fill in a self-report questionnaire. The age range was $18-55(M=22.53, S D=4.49)$.

Measures and procedure. The study was presented as an investigation about concerns young people have in social life. Data for the present study were gathered along with data for other research purposes.

In order to assess individuals' prevention focus orientation (PREV), participants were asked to fill in the General Regulatory Focus Measure (Lockwood, Jordan, \& Kunda, 2002). The prevention focus orientation sub-scale is composed of 9 items (all the items included in our questionnaire are presented in appendix). Participants were asked to indicate their answers 
on a scale ranging from 1 (not at all descriptive of me) to 5 (very descriptive of $m e$ ). Higher scores correspond to higher prevention focus orientation $(\alpha=.74){ }^{1}$

Participants were then asked to complete the others' approval (OA) subscale of the Contingency of Self-Worth Scale (Crocker et al., 2003), composed of five items rated on the same 5-point Likert scale. The items were translated into Italian and back translated for accuracy by a blind judge. Higher scores correspond to higher need for others' approval $(\alpha=$ $.78)$.

As our participants are predominantly young university students, we used 10 out of 24 items $(\alpha=.65)$ of the Junior Self-Monitoring Scale (SM, Graziano, Leone, Musser, \& Lautenschlager, 1987). This scale represents the five theoretical domains that constitute selfmonitoring as depicted by Snyder (1974), but was rephrased in order to make the questions more consistent with the experience of children and adolescents ${ }^{2}$. For the sake of brevity, we selected and translated into Italian 10 items based on two criteria: First, the item-total correlations and the factor loadings emerged in previous research (Graziano et al., 1987; Howells \& Fishfader, 1995); second, the items content prompting the dropping of some items that sounded closer to the construct of self-disclosure rather than self-monitoring (e.g., "There are many things I would only tell to a few of my friends") and others that could have produced a ceiling effect (e.g., "When I'm with my friends I act different than I do with my parents"). The same Italian version was already used in a survey study involving 1688 adolescent participants (Guidetti, Cavazza, \& Conner, under revision). Participants reported to what extent each item was descriptive of them using the previous 5-point response scale. The reliability coefficient found in our sample $(\alpha=.64)$ is acceptable and consistent with those found in other studies using the same scale (Graziano et al., 1987; Guidetti et al., in revision; Howells \& Fishfader, 1995; Perrine \& Aloise-Young, 2004). Higher scores correspond to higher self-monitoring. 
Participants were then invited to answer the Concern for Reputation Scale (CFR) (De Cremer \& Tyler, 2005). For this seven-item scale, participants expressed their agreement on a five-point scale, ranging from 1 (absolutely disagree) to 5 (absolutely agree). Internal reliability of the scale was acceptable $(\alpha=.71)$. Higher scores correspond to higher concern for reputation.

\section{Data analyses}

In order to test the hypothesized mediation model, we adopted a two-step modelling approach (Anderson \& Gerbing, 1988; Kline, 2005). First, we tested the measurement model to assess the extent to which each of the four latent variables was represented by its indicators. Second, we examined the structural component of the hypothesized model through the maximum likelihood estimation using Amos 18 software. In order to control for inflated measurement errors due to multiple items for the latent variables, indicators for the latent variables were defined by parcelling: Three item parcels were built for the prevention focus scale and three for the self-monitoring scale. Two item parcels were computed also for concern for reputation; whereas the five items used as indicators of others' approval were included directly as observed variables. All parcels were computed as the mean of the included item score. To identify the scales of measurement model, we fixed one of the factor loadings to a value of 1 for each latent factor. Evaluation of goodness-of-fit to the sample data was determined on the basis of the chi-squared statistics, Comparative Fit Index (CFI), the root-mean-square error of approximation (RMSEA) and the root-mean-square residual (RMR). Hu and Bentler (1999) suggested that, for a good model fit, RMSEA should be <.06, RMR $<.08$, and CFI should be $>.95$, although any value $>.90$ tends to be considered acceptable.

\section{Results}

Measurement model. The measurement model included four latent constructs (others' approval, prevention focus, self-monitoring, and concern for reputation) and 13 observed 
variables. The first test of the measurement model revealed an acceptable fit to the data: $\chi^{2}$ $(59, \mathrm{~N}=238)=104.53 ; \mathrm{RMSEA}=.057 ; \mathrm{CFI}=.945 ; \mathrm{RMR}=.058$. All the factor loadings for the indicators on the latent variables were significant at $p<.001$. Table 1 shows that the latent constructs were correlated to each other.

Structural model. The direct path coefficients from the two predictors (others' approval and prevention focus) to the criterion (concern for reputation) in the absence of the mediator were significant, $\beta_{\mathrm{OA}}=.34, S E=.07, p<.001 ; \beta_{\mathrm{PREV}}=.26, S E=.08, p=.013$.

The test of the mediation model (Model 1), including self-monitoring as the mediator between others' approval/prevention focus (correlated to each other) and concern for reputation, showed acceptable fit coefficients: $\chi^{2}(59, \mathrm{~N}=238)=104.53$; RMSEA $=.057$; CFI $=.945 ; \mathrm{RMR}=.058$. Both the paths from the predictors to self-monitoring (the mediator) were significant: $\beta_{\mathrm{OA}}=.21, S E=.14, p=.037 ; \beta_{\mathrm{PRE}}=.52, S E=.09, p<.001$, as well as the path from self-monitoring to concern for reputation, $\beta=.44, S E=.21, p<.001$. This corroborates Hypothesis 1. The direct path from prevention focus to concern for reputation became non-significant, $\beta=.02, S E=.14, p=.88$, whereas the direct path from others' approval to concern for reputation remained significant, $\beta=.26, S E=.22, p=.01$. Examination of specific indirect effects via self-monitoring was performed using the Bootstrap estimation procedure in Amos (2000 bootstrapped samples were specified). Both the indirect effects were found to be significant: estimation effect for $\mathrm{OA}=.197, \mathrm{LCI}=.51$, $\mathrm{UCI}=.017$; estimation effect for prevention focus $=.270, \mathrm{LCI}=.106, \mathrm{UCI}=.636$. This is in line with Hypothesis 2.

In synthesis, self-monitoring fully mediated the relationship between prevention focus and concern for reputation, whereas it partially mediated the relationship between others' approval and concern for reputation.

Alternative models. Although Model 1 fit the data well, we also considered two plausible alternative models. The hypothesized model comprises two mediated effects of others' 
approval and prevention focus on concern for reputation via self-monitoring. An alternative possibility is that others' approval, prevention focus and self-monitoring are predictors at the same level of concern for reputation (Model 2). We removed the paths to the mediator from Model 1 while keeping the correlation between others' approval and prevention focus. However, Model 2 presented unacceptable coefficients of fit, $\chi^{2}(61, \mathrm{~N}=238)=156.89$; $\mathrm{RMSEA}=.08 ; \mathrm{CFI}=.88 ; \mathrm{RMR}=.098$.

Since prevention focus motivates individuals to avoid possible damages, this orientation might also stimulate the need to have confirmation from other people about the rightness of their own behaviour, that in turn may make individual sensitive to detect implicit social norms in each specific context (i.e. self-monitoring). Therefore, another alternative model (Model 3) is a multi-step mediation in which prevention focus is a predictor of others' approval that in turn is a predictor of self-monitoring that finally predicts concern for reputation. This model too did not fit the data well: $\chi^{2}(62, \mathrm{~N}=238)=140.79$; $\mathrm{RMSEA}=$ $.073 ; \mathrm{CFI}=.905 ; \mathrm{RMR}=.077$. AIC for Model 1 (168.53) was smaller than that for Model 2 (216.89) and for Model 3 (198.79), providing further justification for the preference for the former (Kline, 2005). The last alternative model would be the one having Concern for reputation as the mediator to Self-monitoring; however we cannot empirically rule out its validity, because the place exchange between CFR and SM would have the same model fit coefficients of our hypothesized model.

Invariance across gender. A one-way analysis of variance, including participants' gender as the independent factor on the four constructs, showed that men and women differed only in the importance of others' approval to self-esteem: Men relied more on validation from others $(M=2.90, S D=.82)$, than women $(M=2.66, S D=.82), F(1,225)=4.37, p=.038$.

In Model 1, invariance across gender through multi-group analysis was studied. All the critical ratios of differences between the structural paths issued from the women and men samples were lower than the |1.96|, the threshold above which two parameter estimates are 
significantly different at $p<.05$. Thus, the paths coefficients in the model did not differ as a function of participants' gender.

\section{Discussion}

Individuals strive to achieve and maintain a good reputation within relevant groups as it provides a number of benefits, both instrumental (including access to valuable resources and the likelihood to influence others) and symbolic (e.g., satisfaction of fundamental esteem needs). A good or bad reputation is fluid by definition, thus people constantly need to act in order to achieve or maintain "the face" in the eyes of relevant others. In the present paper, we proposed and found that the degree to which people are concerned about their reputation is sensitive to personality differences. Recent literature has shown that individuals' concern for reputation varies as a function of contingent context features, such as the degree to which the referential group is perceived as an entity, rather than an aggregate of individuals (Cavazza et al., in press). Nonetheless, despite the indirect evidence stemming from the literature on social image, to date, whether and how personality differences are associated to individual's concern for reputation has not been directly investigated.

According to the model we successfully tested in the present paper, several traits are related to the degree to which individuals are concerned about their own reputation. First, we found evidence that prevention-focused individuals - that is, those people who are mainly focused on preventing failures or losses - are particularly concerned about their reputation. Second, others' approval as a contingency of self-worth was associated to individuals' concern for reputation. This indicates that the more individuals are sensitive to others' approval to gain a positive self-esteem, the more they strive to reach a positive reputation within referential groups. Importantly, we showed that prevention focus and others' approval as contingency of self-worth impact individuals' concern for reputation indirectly by stimulating individual self-monitoring as a proxy of the motivation to comply with implicit social norms. However, in the absence of experimental manipulation mediation analyses 
cannot establish causal inferences, thus we have to regard the model we proposed as an integrated configuration of associations among personality characteristics rather than a causal evidence. Future ad hoc studies should be directed to further confirm our theoretical rationale by means of a direct experimental manipulation. Indeed, a limitation of the present study may be that we cannot empirically rule out an alternative model in which Concern for reputation would be the mediator and Self-monitoring the outcome variable. This is a rather plausible possibility once one considers Self-monitoring as a self-report of typical behavior. However, Oh, Charlier, Mount, \& Berry (2014) recently showed that, depending on situational cues, high self-monitors' actions may or may not be motivated by impression management concern (that is impression management is one of the possible outcomes for high self-monitoring orientation). Thus, we can imagine that even concern for reputation is induced by selfmonitoring in appropriate situations in order to reach high status, rather than predict Selfmonitoring orientation. We believe that this aspect actually raises an important direction for future research as well.

Furthermore, we must acknowledge that the personality traits we considered might appear not so well conceptually distinguished. In particular, it is undeniable that from a conceptual point of view, the others' approval as contingency of self-worth and the concern for reputation are somewhat overlapping constructs. However, it should be noted that the search for others' approval is contingent to each behaviour, whereas being worry for personal reputation refers to the goal of achieving a relatively consolidated and shared positive representation of oneself into a community: Indeed, reputation is the cumulative product of a history of social interactions (Emler \& Hopkins, 1990). Furthermore, the OA scale stresses more than the CFR scale the need for others' approval finalized to self-esteem construction and maintenance, whereas the motivation to enjoy a good reputation (CFR) may also have other ends, such as being accepted as member in valued social groups or acceding to social exchange resources. And in fact, from an empirical point of view, our measurement model 
and factor correlation matrix showed that they are perceived by respondents as separate constructs.

Beyond these cautions, the present research builds on previous findings (Cavazza et al., in press) showing that concern for reputation is not a stable construct as it varies as a function of situational factors (e.g., group entitativity), and extends this evidence by showing that also personal dispositions may affect the efforts individuals put into the process of reputation buildings.

Future research may be directed to investigate whether and how these individual differences interact with contextual factors in determining concern for reputation. For example, it could be interesting to investigate whether this constellation of traits - that is, focus prevention, others' approval as contingency of self-worth, and self-monitoring - are always at work, or whether instead they are particularly important in public (vs. private) circumstances. Again, it would be of great interest to investigate how they lead individuals to take care of their reputation in some specific stages of group socialization (Moreland \& Levine, 1988): They could be particularly important and effective, for instance, during the investigative and the socialization phase, when the newcomers should be more prone to monitor the situation in search of approval. Furthermore, it would be interesting to understand the impact of these traits during the different stages of group development (Tuckman \& Jensen, 1977). It seems reasonable to advance that these traits could be particularly linked to concern for reputation during the forming stage, when the group is concerned with orientation accomplished through testing in order to identify the boundaries of both interpersonal and task behaviours. Here, individuals could take particular care in the reputation building process in order to gain leadership roles. These new avenues should be investigated in future ad hoc studies. Overall, the present paper provides new insights on the antecedents of individuals' care for reputation, by taking into account the role of a number of dispositional features that have been under-investigated with regards to this intriguing topic. 


\section{References}

Anderson, C. \& Shirako, A. (2008). Are individuals' reputations related to their history of behavior? Journal of Personality and Social Psychology, 94, 320-333.

Anderson, J. C., \& Gerbing, D. W. (1988). Structural equation modeling in practice. A review and recommended two-step approach. Psychological Bulletin, 103, 411-423.

Briggs, S. R., \& Cheek, J. M. (1988). On the nature of Self-Monitoring: Problems with assessment, problems with validity. Journal of Personality and Social Psychology, 54, 663-678.

Briggs, S. R., Cheek, J. M. \& Buss, A. H. (1980). An analysis of the Self-Monitoring Scale. Journal of Personality and Social Psychology, 38, 679-686.

Brockner \& Higgings, (2001) Regulatory focus theory: Implications for the study of emotions at work. Organizational Behavior and Human Decision Processes, 86, 35-66.

Bromley, D. B. (1993). Reputation, image, and impression management. Chichester: Wiley.

Cavazza, N. Guidetti, M. \& Pagliaro, S. (submitted). Do we always care about our name? Entitativity and concern for reputation.

Cavazza, N., Graziani, A.R., e Guidetti, M. (2011). Looking for the "right" amount to eat at the restaurant: Social influence effects when ordering. Social Influence, 6, 274-290.

Cooley, C. H. (1902). Human nature and the social order. New York: Scribner's.

Crocker, J., \& Wolfe, C. T. (2001). Contingencies of self-worth. Psychological review, 108, 593.

Crocker, J., Luhtanen, R. K., Cooper, M. L., \& Bouvrette, A. (2003). Contingencies of selfworth in college students: Theory and measurement. Journal of Personality and Social Psychology, 85, 894-908.

Cupach, W.R., \& Metts, S. (1994). Facework. Thousand Oaks, CA: Sage.

De Cremer, D. \& Tyler, T. R. (2005). Am I respected or not? Inclusion and reputation as issues in group membership. Social Justice Research, 18, 121-153. 
Ellemers, N., Pagliaro, S., \& Barreto, M. (in press) Morality and Behavioural Regulation in Groups: A Social Identity Approach. European Review of Social Psychology.

Emler, N. (1990). A social psychology of reputation. European Review of Social Psychology, 1, 171-193.

Emler, N., \& Hopkins, N. (1990). Reputation, social identity, and the self. In D. Abrams \& M.A. Hogg (Eds.), Social identity theory: Constructive and critical advances. New York: Springer-Verlag.

Gangestad, S. W., \& Snyder, M. (2000). Self-monitoring: appraisal and reappraisal. Psychological Bulletin, 126, 530.

Goffman, E. (1959). The Presentation of Self in Everyday Life. University of Edinburgh Social Sciences Research Centre.

Gordon, J.P.F., 1989. Individual morality and reputation costs as deterrents to tax evasion. European Economic Review, 33, 797-805.

Graziano, W. G., Leone, C., Musser, L. M., \& Lautenschlager, G. J. (1987). Self-monitoring in children: A differential approach to social development. Developmental Psychology, 23, 571-576.

Griskevicius, V., Tybur, M.J. \& Van den Bergh, B. (2010). Going green to be seen: Status, reputation, and conspicuous conservation. Journal of Personality and Social Psychology, 98, 392-404.

Guidetti, M., Cavazza, N., \& Conner, M. (in revision). Social influence processes on adolescents' food likes and consumption: the role of parental authoritativeness and individual self-monitoring. .

Higgins, E. T. (1998). Promotion and prevention: Regulatory focus as a motivational principle. In M. P. Zanna (Ed.), Advances in experimental social psychology (Vol. 30, pp. 1-46). New York: Academic Press. 
Hochwarter, W.A., Ferris, G.R., Zinko, R.,Arnell, B., \& James, M. (2007) Reputation as a moderator of political behavior-work outcomes relationships: a two-study investigation with convergent results. Journal of Applied Psychology, 92, 567-76.

Howells, G. N \& Fishfader, V. L. (1995). Personality assessment of adolescents: An analysis of the Junior Self-monitoring Scale. Psychological Reports, 76, 575-578.

Hu, L. T., \& Bentler, P. M. (1999). Cutoff criteria for fit indexes in covariance structure analysis: Conventional criteria versus new alternatives. Structural Equation Modeling, $6,1-55$.

Kline, R. (2005). Principles and practice of structural equation modeling (2nd ed.). London: Guilford Press.

Lalwani, A. K., Shrum, L. J., \& Chiu, C. Y. (2009). Motivated Response styles: The role of cultural values, regulatory focus, and self-consciousness in socially desirable responding. Journal of Personality and Social Psychology, 96, 870-882.

Leary M.R., \& Baumeister, R.F. (2000) The nature and function of self-esteem: Sociometer theory. Advances in Experimental Social Psychology, 32, 1-62.

Lockwood, P., Jordan, C. H., \& Kunda, Z. (2002). Motivation by positive or negative role models: Regulatory focus determines who will best inspire us. Journal of Personality and Social Psychology, 83,854-864.

Maslow, A.H. (1943). A Theory of Human Motivation. Psychological Review 50, 370-396.

Mead, G. H. (1934). Mind, self, and society. Chicago: University of Chicago Press.

Moreland, R. L., \& Levine, J. M. (1988). Group dynamics over time: Development and socialization in small groups. In J. E. McGrath (Ed.), The social psychology of time (pp. 151-181 ). Beverly Hills, CA: Sage.

Oh, I.S., Charlier, S.D., Mount, M.K., \& Berry, C.M. (2014). The two faces of high selfmonitors: Chameleonic moderating effects of self-monitoring on the relationships 
between personality traits and counterproductive work behaviors. Journal of Organizational Behavior, 35(1), 92-111.

Paulhus, D. L. (1984). Two component models of socially desirable responding. Journal of Personality and Social Psychology, 46, 598-609.

Perrine, N. E. \& Aloise-Young, P. A. (2004). The role of self-monitoring in adolescents' susceptibility to passive peer pressure. Personality and Individual Differences, 37, 1701-1716.

Rodriguez Mosquera, P.M., Uskul, A.K. \& Cross, S.E. (2011) The centrality of social image in social psychology, European Journal of Social Psychology, 41 , 403-410.

Semmann, D., Krambeck, H., \& Milinski, M. (2005). Reputation is valuable within and outside one's social group. Behavioral Ecology and Sociobiology, 57, 611-616.

Skowronski, J. J., \& Carlston, D. E. (1987). Social judgment and social memory: The role of cue diagnosticity in negativity, positivity, and extremity biases. Journal of Personality and Social Psychology, 52, 689-699.

Snyder, M. (1974).The self-monitoring of expressive behavior. Journal of Personality and Social Psychology, 30, 526-537.

Snyder, M., \& Gangestad, S. (1982). Choosing social situations: Two investigations of selfmonitoring processes. Journal of Personality and Social Psychology, 43, 123-135.

Tinsley, C. H., O’Connor, K. M., \& Sullivan, B. A. (2002). Tough guys finish last: The perils of a distributive reputation. Organizational Behavior and Human Decision Processes, $88,621-645$.

Tuckman, B, W., \& Jensen, M. (1977). Stages of small-group development revisited. Group \& Organization Studies, 2, 419-427.

Ybarra, O., Park, H. Stanik, C., \& Lee, D.S. (2012). Self-judgment and reputation monitoring as a function of the fundamental dimensions, temporal perspective, and culture. European Journal of Social Psychology, 42, 200 - 209. 


\section{Footnotes}

1. To be sure that the trait of interest was prevention, rather than promotion regulatory focus, a subsample of 133 participants completed both prevention and promotion focus scales, as well as concern for reputation items: Although both prevention and promotion are significantly correlated with concern for reputation $(r=.218, p=.012$ and $r=.197, p=.039$, respectively), when simultaneously entered into a linear regression model, only prevention focus significantly predicted the dependent variable, $\beta=.18, t=1.99, p=.049$.

2. As we administered that scale to university students, we also rephrased four items to make them more general and more suitable to the experience of university students, replacing "classmates" with "friends", "teacher" with a general "people", and "when a new person come to school" with "when I meet a new person" (see the Appendix). 
Table 1.

Descriptive statistics and correlations for all measures.

\begin{tabular}{|l|l|l|l|l|}
\hline & $M(S D)$ & 1 & 2 & 3 \\
\hline 1. OA & $2.80(.83)$ & 1 & & \\
\hline 2. PREV & $3.07(.73)$ & $34 * * *$ & 1 & \\
\hline 3. SM & $2.26(.52)$ & $.32 * * *$ & $.42 * * *$ & 1 \\
\hline 4. CFR & $3.26(.92)$ & $.34 * * *$ & $.26 * * *$ & $.35^{* * *}$ \\
\hline
\end{tabular}

Note. OA, others' approval subscale of the contingency of self-worth scale; PREV, prevention focus; SM, Self-monitoring; CFR, Concern for reputation.

$* * * p<.001$ 
Figure 1. The final structural model $(\mathrm{N}=238)$.

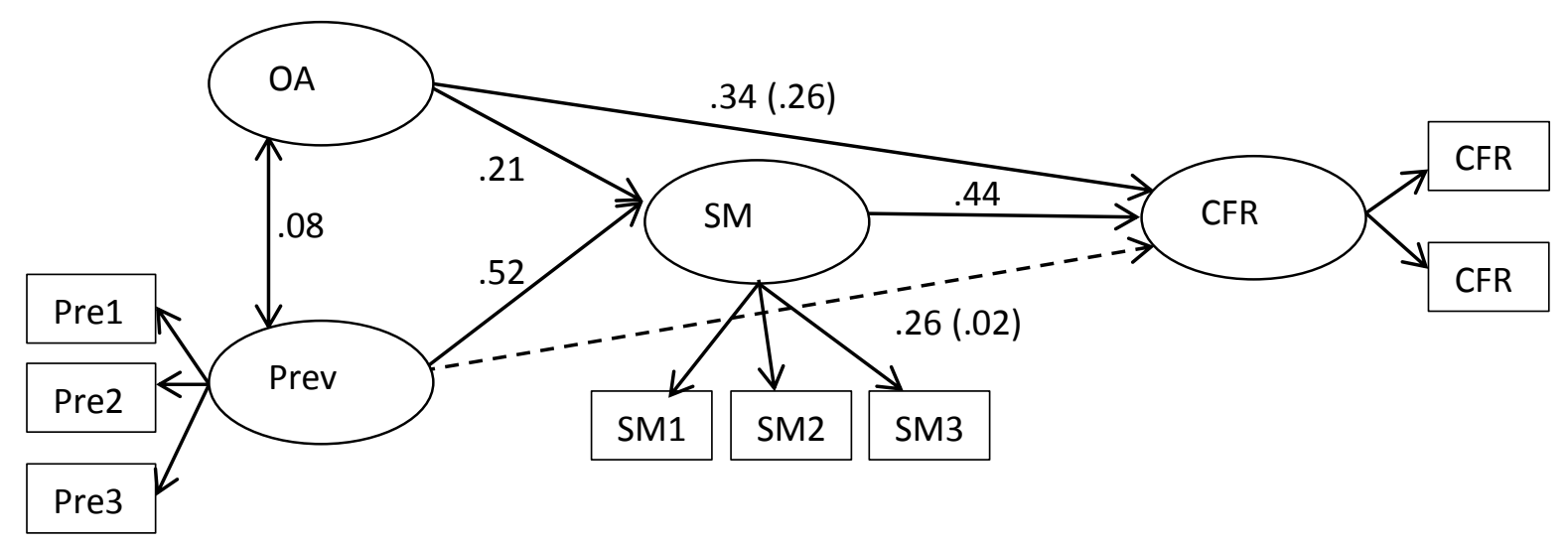


Appendix

Prevention Orientation sub-scale (Lockwood et a., 2002)

\begin{tabular}{|l|l|}
\hline $\begin{array}{l}\text { 1. In general, I am focused on preventing } \\
\text { negative events in my life. }\end{array}$ & $\begin{array}{l}\text { In generale, mi dò molto da fare per evitare } \\
\text { che nella mia vita si verifichino eventi } \\
\text { spiacevoli. }\end{array}$ \\
\hline $\begin{array}{l}\text { 2. I am anxious that I will fall short of my } \\
\text { responsibilities and obligations. }\end{array}$ & $\begin{array}{l}\text { L'idea di non riuscire a far fronte ai miei } \\
\text { obblighi e alle mie responsabilità mi mette } \\
\text { in ansia. }\end{array}$ \\
\hline $\begin{array}{l}\text { 3. } \\
\text { I often think about the person I am afraid } \\
\text { I might become in the future. }\end{array}$ & $\begin{array}{l}\text { Penso spesso alla persona che ho paura di } \\
\text { diventare nel futuro. }\end{array}$ \\
\hline 4. $\begin{array}{l}\text { I often worry that I will fail to } \\
\text { accomplish my academic goals. }\end{array}$ & $\begin{array}{l}\text { Spesso mi preoccupo di non riuscire a } \\
\text { raggiungere i miei obiettivi di studio/lavoro. }\end{array}$ \\
\hline 5. $\begin{array}{l}\text { I often imagine myself experiencing bad } \\
\text { things that I fear might happen to me. }\end{array}$ & $\begin{array}{l}\text { Spesso, con l'immaginazione, fantastico di } \\
\text { vivere delle cose brutte, delle quali ho paura. }\end{array}$ \\
\hline $\begin{array}{l}\text { 6. } \\
\text { I frequently think about how I can } \\
\text { prevent failures in my life. }\end{array}$ & $\begin{array}{l}\text { Penso spesso a come prevenire i fallimenti } \\
\text { nella mia vita. }\end{array}$ \\
\hline 7. $\begin{array}{l}\text { I am more oriented toward preventing } \\
\text { losses than I am toward achieving gains. }\end{array}$ & $\begin{array}{l}\text { Sono più orientato a prevenire perdite che a } \\
\text { cercare i guadagni. }\end{array}$ \\
\hline $\begin{array}{l}\text { 8. } \\
\text { My major goal in school right now is to } \\
\text { avoid becoming an academic failure. }\end{array}$ & $\begin{array}{l}\text { In questo momento, il mio principale } \\
\text { obiettivo lavorativo è quello di evitare di } \\
\text { diventare un fallimento. }\end{array}$ \\
\hline $\begin{array}{l}\text { 9. } \\
\text { I see myself as someone who is } \\
\text { primarily striving to become the self I } \\
\text { "ought" to be- to fulfill my duties, } \\
\text { responsibilities, and obligations. }\end{array}$ & $\begin{array}{l}\text { Mi vedo come una persona che cerca } \\
\text { soprattutto di diventare ciò che «dovrebbe», } \\
\text { vale a dire di assolvere i propri obblighi, } \\
\text { doveri e responsabilità. }\end{array}$ \\
\hline
\end{tabular}

Others' Approval sub-scale of the Contingencies of Self Worth Scale (Crocker et al., 2003)

\begin{tabular}{|c|c|}
\hline $\begin{array}{l}\text { 1. I don't care what other people think of } \\
\text { me. }^{\text {a }}\end{array}$ & $\begin{array}{l}\text { Non mi importa di quello che gli altri } \\
\text { pensano di me. }{ }^{\text {a }}\end{array}$ \\
\hline $\begin{array}{l}\text { 2. What others think of me has no effect on } \\
\text { what I think about myself. }{ }^{\text {a }}\end{array}$ & $\begin{array}{l}\text { Quello che gli altri pensano di me non } \\
\text { influenza quello che io penso di me } \\
\text { stesso/a. }{ }^{\text {a }}\end{array}$ \\
\hline $\begin{array}{l}\text { 3. I don't care if other people have a } \\
\text { negative opinion about me. }{ }^{\text {a }}\end{array}$ & $\begin{array}{l}\text { Non mi interessa se le altre persone hanno } \\
\text { un'opinione negative di me. }\end{array}$ \\
\hline $\begin{array}{l}\text { 4. My self-esteem depends on the opinions } \\
\text { others hold of me. }\end{array}$ & $\begin{array}{l}\text { La mia autostima dipende dai giudizi degli } \\
\text { altri. }\end{array}$ \\
\hline $\begin{array}{l}\text { 5. I can't respect myself if others don't } \\
\text { respect me. }\end{array}$ & $\begin{array}{l}\text { Non riesco ad avere rispetto per me stesso/a } \\
\text { se gli altri non mi rispettano. }\end{array}$ \\
\hline
\end{tabular}

Self-Monitoring Scale (from the JSMS by Graziano et al., 1987)

\begin{tabular}{|l|l|}
\hline $\begin{array}{l}\text { 1. I sometimes wear some kinds of clothes } \\
\text { just because my friends are wearing that } \\
\text { kind. }\end{array}$ & $\begin{array}{l}\text { Mi capita di indossare certi vestiti perché li } \\
\text { indossano i miei amici/le mie amiche. }\end{array}$ \\
\hline $\begin{array}{l}\text { 2. Sometimes I clown around so my friends } \\
\text { will like me. }\end{array}$ & $\begin{array}{l}\text { A volte faccio il pagliaccio per piacere ai } \\
\text { miei amici / alle mie amiche. }\end{array}$ \\
\hline $\begin{array}{l}\text { 3. When I am not sure how to act I watch } \\
\text { others to see what to do. }\end{array}$ & $\begin{array}{l}\text { Quando non so bene come comportarmi, } \\
\text { guardo gli altri per capire cosa fare. }\end{array}$ \\
\hline
\end{tabular}




\begin{tabular}{|c|c|}
\hline $\begin{array}{l}\text { 4. I laugh more when I watch funny TV } \\
\text { shows with other people than when I } \\
\text { watch them alone. }\end{array}$ & $\begin{array}{l}\text { Se guardo un programma divertente in } \mathrm{TV} \text {, } \\
\text { rido di più quando sono in compagnia che } \\
\text { quando sono da solo. }\end{array}$ \\
\hline $\begin{array}{l}\text { 5. When I'm afraid of someone I try to be } \\
\text { nice to them so they will not bother me. }\end{array}$ & $\begin{array}{l}\text { Quando temo qualcuno, cerco di essere } \\
\text { gentile con lui/lei in modo che non mi dia } \\
\text { fastidio. }\end{array}$ \\
\hline $\begin{array}{l}\text { 6. I try to figure out how people wants me } \\
\text { to act and then that's how I try to act. }\end{array}$ & $\begin{array}{l}\text { Cerco di capire cosa si aspettano da me le } \\
\text { persone e cerco di accontentarle. }\end{array}$ \\
\hline $\begin{array}{l}\text { 7. I feel embarrassed when I don't have the } \\
\text { same kind of clothes as my friends. }\end{array}$ & $\begin{array}{l}\text { Mi sento in imbarazzo se sono vestito in } \\
\text { modo molto diverso dai miei amici/amiche. }\end{array}$ \\
\hline $\begin{array}{l}\text { 8. When I meet a new person, I listen to } \\
\text { what my friends say before I decide } \\
\text { whether I like that new person. }\end{array}$ & $\begin{array}{l}\text { Di fronte ad una persona nuova, quello che } \\
\text { dicono i miei amici mi aiuta a decidere se } \\
\text { quella persona mi piace o no. }\end{array}$ \\
\hline $\begin{array}{l}\text { 9. I can make people think I'm happy even } \\
\text { if I'm not happy. }\end{array}$ & $\begin{array}{l}\text { Posso far credere agli altri che sono felice } \\
\text { anche se non lo sono. }\end{array}$ \\
\hline $\begin{array}{l}\text { 10. I feel unhappy when I don't have the } \\
\text { things that my friends have. }\end{array}$ & $\begin{array}{l}\text { Mi sento triste quando non ho quello che } \\
\text { hanno i miei amici. }\end{array}$ \\
\hline
\end{tabular}

Concern for Reputation Scale (De Cremer \& Tyler, 2005)

\begin{tabular}{|c|c|}
\hline $\begin{array}{l}\text { 1. I am rarely concerned about my } \\
\text { reputation. }\end{array}$ & $\begin{array}{l}\text { Sono raramente preoccupato della mia } \\
\text { reputazione. }\end{array}$ \\
\hline $\begin{array}{l}\text { 2. I do not consider what others say about } \\
\text { me. }\end{array}$ & $\begin{array}{l}\text { Non mi interessa quello che gli altri dicono di } \\
\text { me. }{ }^{\text {a }}\end{array}$ \\
\hline 3. I wish to have a good reputation. & Desidero avere una buona reputazione. \\
\hline $\begin{array}{l}\text { 4. If my reputation is not good, I feel very } \\
\text { bad. }\end{array}$ & Se non ho una buona reputazione mi dispiace. \\
\hline $\begin{array}{l}\text { 5. I find it important that others consider my } \\
\text { reputation as a serious matter. }\end{array}$ & $\begin{array}{l}\text { Per me è importante che gli altri prendano sul } \\
\text { serio la mia reputazione. }\end{array}$ \\
\hline $\begin{array}{l}\text { 6. I try hard to work on my reputation (in my } \\
\text { relationships with others). }\end{array}$ & $\begin{array}{l}\text { Nelle relazioni con gli altri, mi impegno per } \\
\text { avere una buona reputazione. }\end{array}$ \\
\hline $\begin{array}{l}\text { 7. I find it difficult if others paint an } \\
\text { incorrect image of me. }\end{array}$ & $\begin{array}{l}\text { Se gli altri mi dipingessero in modo negativo, } \\
\text { farei fatica ad accettarlo. }\end{array}$ \\
\hline
\end{tabular}

\footnotetext{
${ }^{\text {a }}$ Reversed score.
} 